This article was downloaded by: [ETHZ - Bibliothek]

On: 8 March 2011

Access details: Access Details: [subscription number 919489118]

Publisher Taylor \& Francis

Informa Ltd Registered in England and Wales Registered Number: 1072954 Registered office: Mortimer House, 3741 Mortimer Street, London W1T 3JH, UK

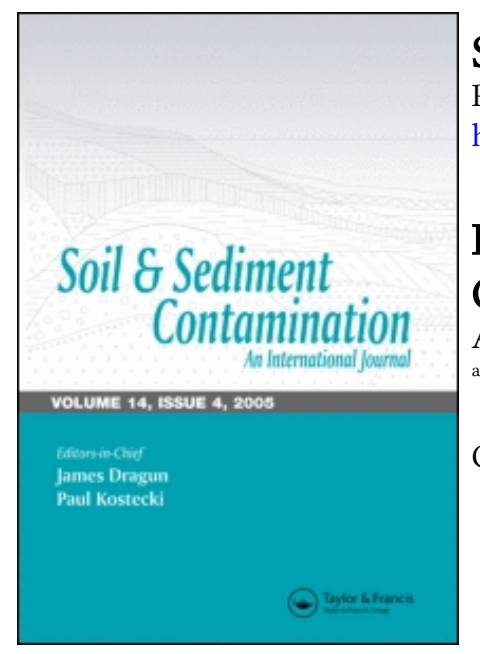

Soil and Sediment Contamination: An International Journal

Publication details, including instructions for authors and subscription information:

http://www.informaworld.com/smpp/title content=t713401148

\title{
Landfarming Process Effects on Biochemical Properties of Petroleum- Contaminated Soils
}

A. Besalatpour ; ;. A. Hajabbasia; A. H. Khoshgoftarmanesha; V. Dorostkar

a Department of Soil Sciences, College of Agriculture, Isfahan University of Technology, Isfahan, Iran

Online publication date: 03 March 2011

To cite this Article Besalatpour, A. , Hajabbasi, M. A. , Khoshgoftarmanesh, A. H. and Dorostkar, V.(2011) 'Landfarming Process Effects on Biochemical Properties of Petroleum-Contaminated Soils', Soil and Sediment Contamination: An International Journal, 20: 2, 234-248

To link to this Article: DOI: $10.1080 / 15320383.2011 .546447$

URL: http://dx.doi.org/10.1080/15320383.2011.546447

\section{PLEASE SCROLL DOWN FOR ARTICLE}

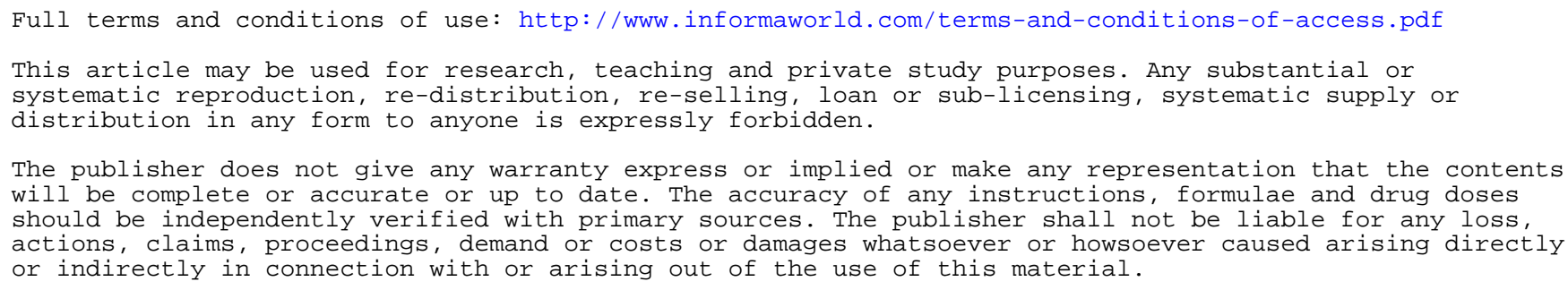




\title{
Landfarming Process Effects on Biochemical Properties of Petroleum-Contaminated Soils
}

\author{
A. BESALATPOUR, M. A. HAJABBASI, A. H. \\ KHOSHGOFTARMANESH, AND V. DOROSTKAR \\ Department of Soil Sciences, College of Agriculture, Isfahan University \\ of Technology, Isfahan, Iran
}

\begin{abstract}
The presence of petroleum contaminants in soil may be toxic to humans, plants, and soil microorganisms. Therefore, remediation of these compounds from the environment is vital. In this study, bioremediation of two petroleum-contaminated soils $\left(S_{1}\right.$ and $\left.S_{2}\right)$ using a landfarming technique was evaluated. Investigation of the effect of this technique on biological and chemical properties of contaminated soil was also part of the goal. The results showed that about 50 and 57\% of hydrocarbon contents were eliminated from soils $S_{1}$ and $S_{2}$ at the end of the experiment, respectively. Landfarming processes enhanced microbial respiration rate in both soils $S_{1}$ and $S_{2}$. Microbial biomass-nitrogen values in the landfarming plots were significantly $(\mathrm{P}<0.05)$ higher than in the control plots (without landfarming operations). Urease activity increased by 21, 45, 26, and $23 \%$ in the landfarming plots as compared to the control plots for soil $S_{2}$ at the end of first to the 4th month of the experiment, respectively. There was also significant difference $(\mathrm{P}<0.05)$ in soil $p H$ values between the landfarming treatment and control. Soil electrical conductivity in the landfarming plots was lower than in the controls. Total organic matter and total nitrogen contents in the landfarming plots were significantly lower in comparison to the control plots. It appears that improving soil aeration and exposing new layers of soil to sunlight and air as a result of landfarming operations facilitated the degradation of petroleum hydrocarbons.
\end{abstract}

Keywords bioremediation, landfarming, microbial activity, petroleum contaminants

\section{Introduction}

Large quantities of soil have been contaminated with petroleum hydrocarbons through transportation, leakage from tanks, accidental spillage, pipeline ruptures, or in the case of deliberate spreading of oily wastes like in landfilling operations (Siddiqui and Adams, 2002; Besalatpour et al., 2008). Presence of these contaminants in soil may be toxic to humans, plants, and soil microorganisms and there is a serious concern due to their recalcitrant and mutagenic/carcinogenic properties (Siddiqui and Adams, 2002; Xu et al., 2006). Therefore, there are urgent needs to find effective and low-cost technologies to clean up these contaminated soils.

Physical, chemical, and biological methods can all be used for remediation of such contaminated soils, but landfarming has been recognized as a feasible and low cost-effective

Address correspondence to A. Besalatpour, Department of Soil Sciences, College of Agriculture, Isfahan University of Technology, Isfahan 84156 8311, Iran. E-mail: a_besalatpour@ag.iut.ac.ir 
technique for removal of total petroleum hydrocarbons (TPHs) from soil (Al-Awadhi et al., 1996; Picado et al., 2001; Giasi and Morelli, 2003; Petavy et al., 2009). This technology is also considered to be economical, energy efficient, and environmentaly friendly with minimal residue disposal problems (Hejazi et al., 2003). Landfarming, known as land treatment or land application, is an above-ground remediation technology for soil that reduces concentration of petroleum constituents through biodegradation (Hejazi et al., 2003). Such landfarming involves the use of natural biological, chemical, and physical processes in the petroleum-contaminated soil to transform the organic contaminants of concern (Pope and Matthews, 1993). This technology usually involves spreading excavated contaminated soil in a thin layer on the ground surface and stimulating aerobic microbial activity within the soils through aeration and/or the addition of mineral nutrient and moisture (API, 1983; Giasi and Morelli, 2003).

Landfarming gained popularity over incineration, landfilling, and deep well injection due to its following distinct merits (Huddleston and Meyers, 1979): low energy consumption, low risk of pollution of the surface and groundwater due to the immobility of hydrocarbons or metals through the soil, minimal impact on the environment (good site appearance, absence of odors, etc.), relatively low cost, compliance with sound industrial practices and/or government regulations, minimal residue disposal problems, and compatibility of the technique with the climate, location, and soil properties.

Soil properties that are important in influencing the rate and extent of the remediation of petroleum-contaminated soils include texture, bulk density, hydraulic conductivity, cation exchange capacity (CEC), nutrient status, and soil microorganism types and numbers. However, parameters indicative of metabolic activity (biological and biochemical parameters) have been scarcely studied in soils with waste petroleum subjected to landfarming (Atlas, 1981; Pope and Matthews, 1993).

There are several oil refineries in Iran (e.g. Tehran Oil Refinery) where environmental pollution is increasingly becoming a great concern and thus the ecosystem is subjected to serious challenges. Different approaches to reduce this problem have failed so far (Besalatpour et al., 2008). Hence, in this study we evaluated the potential use of a landfarming technique to eliminate petroleum compounds from contaminated soils. Furthermore, the effect of landfarming technique on microbial activity indicators and chemical properties of petroleum-contaminated soils as a function of time was investigated.

\section{Materials and Methods}

\section{Soil Preparation}

Bulk samples (about $500 \mathrm{Kg}$ ) of petroleum-contaminated soils were collected from oily wastes land fill soil (soil $\mathrm{S}_{1}$ ) and petroleum-contaminated farm lands (soil $\mathrm{S}_{2}$ ) around the Tehran Oil Refinery $\left(35^{\circ} 30^{\prime} \mathrm{N}, 51^{\circ} 26^{\prime} \mathrm{E}\right)$, Iran. Soil samples were air dried, passed through a 4-mm sieve, land farmed, and mixed at intervals every 3 days with a garden hoe for 21 days to ensure a homogenous distribution of the petroleum pollutants. After that, a total of approximately $1 \mathrm{~kg}$ subsamples of the treated soils were sieved through a 2-mm sieve and used for physiochemical analysis (Table 1).

\section{PAH and TPH Analysis}

Petroleum hydrocarbon-contents in the soil samples were extracted by soxhlet using a 1:1 (v/v) dichloromethane and n-hexane (150 ml) mixture for $24 \mathrm{~h}$ (Christopher et al., 1988). 
Table 1

Physiochemical properties of soils sampled from oily waste landfill (soil $\mathrm{S}_{1}$ ) and petroleumcontaminated farm lands (soil $\mathrm{S}_{2}$ )

\begin{tabular}{lrr}
\hline & & Soil \\
\cline { 2 - 3 } Characteristic & \multicolumn{1}{c}{$\mathrm{S}_{1}$} & $\mathrm{~S}_{2}$ \\
\hline Clay $(\%)$ & 20 & 25 \\
$\mathrm{CaCO}_{3}(\%)$ & 20 & 29 \\
Available-Mg $\left(\mathrm{mg} \mathrm{kg}^{-1}\right)$ & 219 & 132 \\
Available-Ca $\left(\mathrm{mg} \mathrm{kg}^{-1}\right)$ & 620 & 532 \\
Available-Na $\left(\mathrm{mg} \mathrm{kg}^{-1}\right)$ & 51 & 39 \\
Available-P $\left(\mathrm{mg} \mathrm{kg}^{-1}\right)$ & 125 & 145 \\
Available-K $\left(\mathrm{mg} \mathrm{kg}^{-1}\right)$ & 200 & 230 \\
DTPA-Mn $\left(\mathrm{mg} \mathrm{kg}^{-1}\right)$ & 49 & 28 \\
DTPA-Zn $\left(\mathrm{mg} \mathrm{kg}^{-1}\right)$ & 18 & 15 \\
DTPA-Cu $\left(\mathrm{mg} \mathrm{kg}^{-1}\right)$ & 81 & 52 \\
DTPA-Fe $\left(\mathrm{mg} \mathrm{kg}^{-1}\right)$ & 71 & 85 \\
DTPA-Ni $\left(\mathrm{mg} \mathrm{kg}^{-1}\right)$ & 4 & 2 \\
\hline
\end{tabular}

The concentration of polycyclic aromatic hydrocarbons (PAHs) was then determined in the extracts by means of gas-chromatograph (GC) with a Delsi DI 200 chromatograph equipped with a direct injection port and a FID detector at $340^{\circ} \mathrm{C}$ (Table 2). The carrier gas was helium under $0.08 \mathrm{MPa}$ and the column was a CP Sil 5 CB (Chrompack) capillary column ( $50 \mathrm{~m}$ by $0.32 \mathrm{~mm}$, film thickness $0.25 \mu \mathrm{m}$ ).

\section{Landfarming Experiments}

Three plots with about $30000 \mathrm{~cm} 3$ volumes for carrying out the bioremediation processes (landfarming) and another three for control plots (without landfarming operations) were conducted in an open field. Landfarming processes consisted of irrigation (near the 0.7 field capacity) and aerating the contaminated soil every 3 days by hand mixing with a garden hoe. The soils were turned over before irrigation to expose a new layer of soil to sunlight and air. Control plots were also treated in the same way as landfarming plots but without irrigation and aeration. Conditions were totally natural with no nutrients added. The entire experiment was run for 4 months from October (2007) to January (2008) and soil samples were taken from each plot before irrigation and aeration processes at the end of each month (1st, 2nd, 3rd, and 4th months). Composite soil samples of the top $5 \mathrm{~cm}$ were randomly collected from three different places in each plot. The samples were brought to the laboratory on the same day and were kept in the refrigerator at $4{ }^{\circ} \mathrm{C}$ until they were analyzed (microbiological analysis were carried out 3-4 days after sampling).

\section{Microbiological Analysis}

Microbial biomass-nitrogen (MB-N) was determined by the chloroform-fumigationincubation method (Horwath and Paul, 1994). This method involves the incubation of fumigated and non-fumigated samples in 125-ml Nalgene bottles placed in a desiccators at $25^{\circ} \mathrm{C}$ for $24 \mathrm{~h}$ in the dark and the extraction of $\mathrm{NH}_{4}^{+}-\mathrm{N}$ and $\mathrm{NO}_{3}^{-}-\mathrm{N}$ with $75 \mathrm{ml}$ of $2 \mathrm{M}$ 
Table 2

Concentrations of measured PAHs and TPHs in the soils $\mathrm{S}_{1}$ and $\mathrm{S}_{2}$

\begin{tabular}{|c|c|c|}
\hline \multirow[b]{2}{*}{ PAHs $\left(\mathrm{mg} \mathrm{kg}^{-1}\right)$} & \multicolumn{2}{|c|}{ Soil } \\
\hline & $\mathrm{S}_{1}$ & $\mathrm{~S}_{2}$ \\
\hline Naphthalene & 42 & 17 \\
\hline Acenaphthylene & nd & nd \\
\hline Phenanthrene & 31 & 15 \\
\hline Anthracene & 2 & 0.5 \\
\hline Fluoranthene & 26 & 21 \\
\hline Flourene & nd & nd \\
\hline Pyrene & 18 & 10 \\
\hline Chrysene & nd & nd \\
\hline Benzo[k]fluoranthene & nd & 32 \\
\hline Benzo[b]fluoranthene & nd & nd \\
\hline Benzo[a]anthracene & nd & nd \\
\hline Benzo[a]pyrene & 43 & 33 \\
\hline Benzo[e]pyrene & 42 & 21 \\
\hline Benzo[g,h,i]perylene & 7 & 9 \\
\hline 1-methyl phenanthrene & nd & nd \\
\hline 2-methyl phenanthrene & 21 & 11 \\
\hline Indeno & nd & $\mathrm{Nd}$ \\
\hline TPHs $\left(\mathrm{mg} \mathrm{kg}^{-1}\right)$ & 108960 & 73230 \\
\hline
\end{tabular}

nd: not detected by gas chromatography.

$\mathrm{KCl}$ (soil: $\mathrm{KCl}$ solution ratio = 1:5) after shaking for $30 \mathrm{~min}$, centrifuging for $10 \mathrm{~min}$ and filtering the resulting supernatant through a Whatman No. 42 filter paper. The MB-N was calculated using the $\mathrm{NH}_{4}^{+}-\mathrm{N}$ extracted, which was determined in a 20 -ml aliquot by steam distillation (Keeney and Nelson, 1982). The basal soil microbial respiration was measured as evolved $\mathrm{CO}_{2}$. For this purpose, 3 replicate soil samples of each treatment were incubated for three days at $26^{\circ} \mathrm{C}$ in 250 -ml glass containers closed with rubber stoppers. The evolving $\mathrm{CO}_{2}$ was trapped in $\mathrm{NaOH}$ solution and the excess in alkali was then titrated with $\mathrm{HCl}$. Three glass containers with $\mathrm{NaOH}$ but without soil were also used as controls (Alef, 1995). Urease activity was measured using Alef and Nannipieri (1995) method. Five g of soil samples were placed in an Erlenmeyer flask $(100 \mathrm{ml})$ and then $2.5 \mathrm{ml}$ urea solution was added to it. A control without urea was also used with each sample. Afterward, the Erlenmeyer flasks were incubated for $2 \mathrm{~h}$ at $37^{\circ} \mathrm{C}$. After incubation, $50 \mathrm{ml}$ of $\mathrm{KCl}$ solution was added to each sample and then the mixture was shaken for $30 \mathrm{~min}$. After filtering the resulted suspension, the filtrates were analyzed for the ammonium content.

\section{Chemical Analysis}

Electrical conductivity (EC) and soil $\mathrm{pH}$ were measured in a 1/5 solid/liquid aqueous extract. Total organic matter (TOM) was determined using the Wakley-Black method (Nelson and Sommers, 1982). Total nitrogen (TC) was measured by the micro-Kjeldahl 
method (Bremner and Mulvaney, 1982). Moreover, soil TPH concentration in each sample was measured according to the procedure of Christopher et al. (1988).

\section{Statistical Analysis}

The experiment was arranged in a factorial trail with completely randomized block design and analysis of variance was performed using SAS statistical computer program (SAS Institute, 1999). Furthermore, the least significant difference (LSD) values were used to establish the significance of differences.

\section{Results and Discussion}

\section{Climate Conditions}

Climate conditions, in particular temperature and daylight hours, have a great effect on soil microbial activity and thus influence the degradation of petroleum hydrocarbons by landfarming technique (Merkle et al., 2005). In addition, the temperature increase may contribute to enhance the bioavailability of hydrocarbon contaminants that are less soluble at lower temperatures (Coulon et al., 2005). Therefore, in this study daily temperature (maximum, minimum, and mean) and daylight hours were measured during the experiment (Fig. 1). The daily maximum and minimum temperatures during the first 2 months of the experiment (October and November) were higher than the last 2 months (December and January), especially the last month when the daily maximum temperature was lower than $10^{\circ} \mathrm{C}$. Daily mean temperature during most of October and November was higher than $15^{\circ} \mathrm{C}$, while the lowest daily mean temperatures were observed during the last days of the
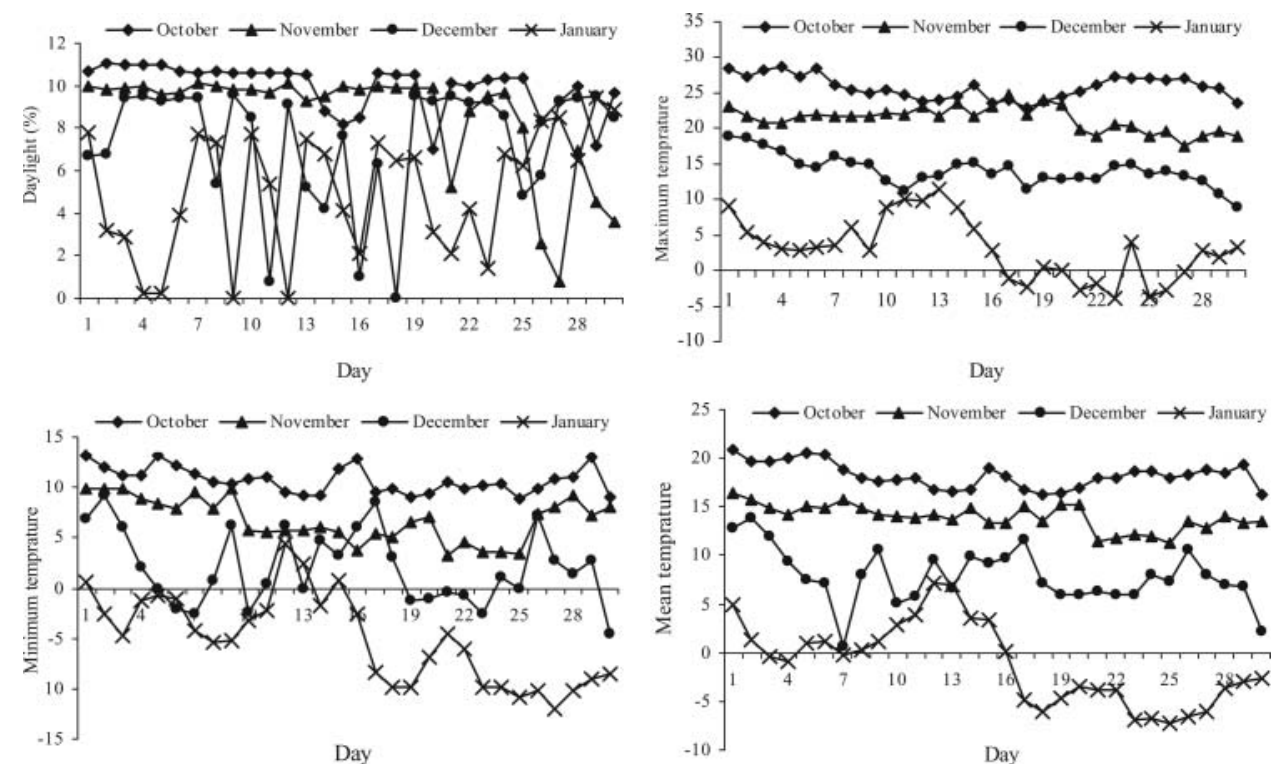

Figure 1. Daily temperature (max, min, and mean) and daylight hours during the landfarming experiment. 
experiment. Furthermore, most days of the first 2 months of the experiment were sunny with more than $10 \mathrm{~h}$ daylight at each day. On the other hand, most days of the last 2 months of the experiment were cloudy.

\section{Landfarming Effects on Soil Biological Properties}

In a soil where landfarming processes are being carried out (for instance, for reducing the hydrocarbon content), microbial population and its activity could be influenced for those processes. Therefore, study of some parameters indicative of microbial activity like soil microbial respiration rate, enzyme activities, and microbial biomass can be of interest (Marin et al., 2005). The measurement of soil microbial respiration rate gives an idea of microbial activity in soil as well as the quantity and quality of substrates that are susceptible to mineralization (Anderson, 1982). Soil enzymes are also predominantly of microbial origin and are closely related to microbial abundance; hence they can be used to assay microbial activity and community (Insam, 2001). In addition, microbial biomass is a robust parameter that allows gross comparisons of soils, and reflects soil management changes or pollution impact and has been frequently used for understanding soil microbial activity and community (Insam, 2001). In this study, soil microbial respiration rate, urease activity, and microbial biomass-nitrogen were measured as indicators of soil microbial community and/or activity:

1. Microbial Respiration. The $\mathrm{CO}_{2}$ emission due to microbial respiration in the landfarming plots was significantly $(P<0.05)$ higher than in the control plots (without landfarming operations) for both soils $S_{1}$ and $S_{2}$ (Fig. 2). There were 50, 36, 20, and $45 \%$ increases in microbial respiration rate in the landfarming plots as compared to the controls for soil $\mathrm{S}_{1}$ at the end of first to the 4th month of the experimental period, respectively. Also, the $\mathrm{CO}_{2}$ emission in the landfarming plots for soil $\mathrm{S}_{2}$ was about $39,31,38$, and $40 \%$ higher than in the control plots. Improving soil conditions for microorganism activities due to landfarming operations (aerating, providing optimal soil moisture, and exposing new layers of soil to sunlight) apparently intensified soil microbial activity and thus the $\mathrm{CO}_{2}$ emission in the soils increased with time (Leiros et al., 1999; Marin et al., 2005). Moreover, microbial respiration rate in both soils $S_{1}$ and $S_{2}$ at the end of last 2 months of the experiment was lower than that at the end of first 2 months (Fig. 2). Lower daily mean temperatures during the last 2 months of the experiment (especially the 4th month) in comparison to the first 2 months (Fig. 1) may have been a limiting factor for soil microbial activity. Furthermore,
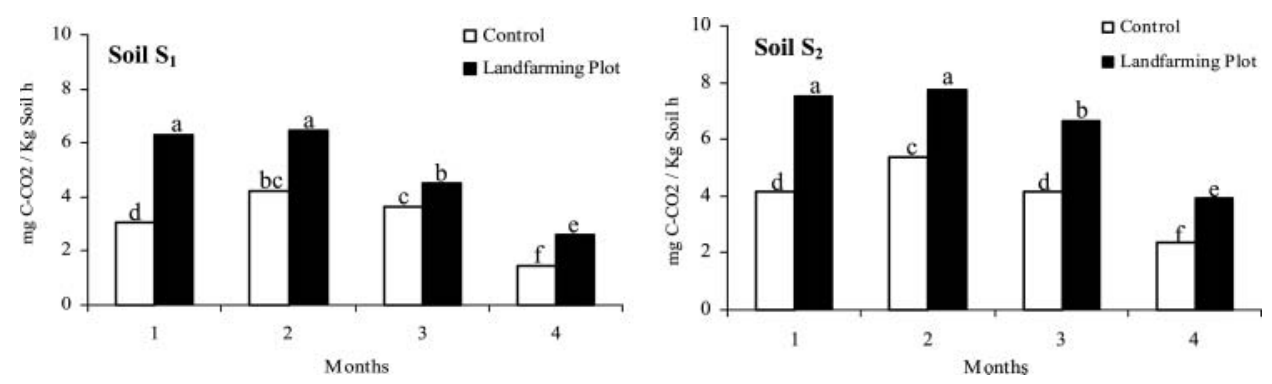

Figure 2. Microbial respiration (evolved $\mathrm{CO}_{2}$ ) in soils $\mathrm{S}_{1}$ and $\mathrm{S}_{2}$ during the landfarming experiment. Different letters denote significant differences at $P<0.05$. 

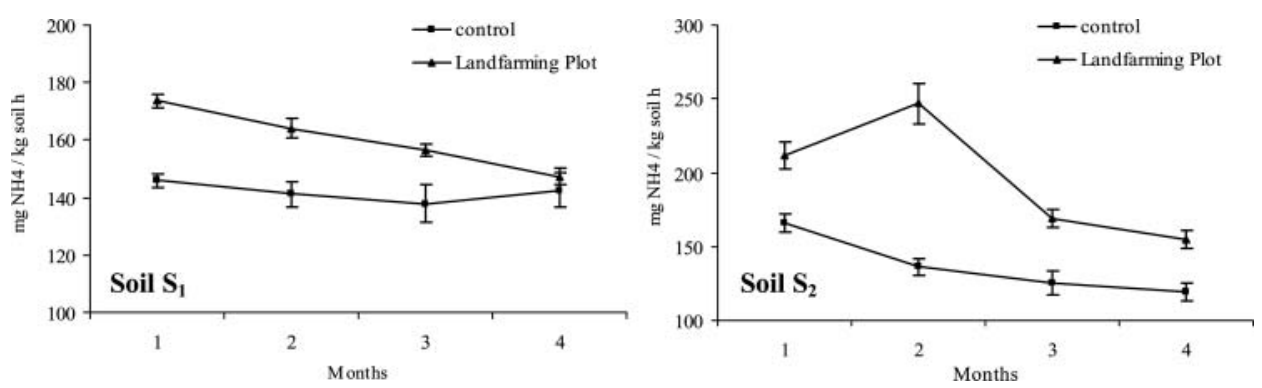

Figure 3. Urease activity in soils $S_{1}$ and $S_{2}$ during the landfarming experiment.

the degradation and mineralization of labile hydrocarbons during the first days of the experimental period can be considered as a negative factor for the decreases of soil microbial respiration rate at the end of last 2 months (Davidson et al., 1998; Leiros et al., 1999).

In a similar study, Riffaldi et al. (2006) reported significant increases in soil microbial respiration in petroleum-contaminated soil in the bioremediation treatments. Marin et al. (2005) concluded that the $\mathrm{CO}_{2}$ emission decreased gradually with time when the most labile hydrocarbon fractions were degraded and eliminated. They also added that such behavior is very susceptible to humidity and temperature. Franco et al. (2004) found that soil contamination with crude oil caused a variable increase in cumulative $\mathrm{CO}_{2}$ emissions. Balba et al. (1998) reported that in bioremediation studies the measurement of total $\mathrm{CO}_{2}$ production can provide excellent information on the biodegradability potential of hydrocarbons in contaminated soils.

2. Urease Activity. Urease activity in the landfarming plots was significantly $(P<0.05)$ higher than in the control plots; however, no significant differences were observed among the landfarming plots and controls for soil $S_{1}$ at the end of the 4th month of the experiment (Fig. 3). There were 16,14, and 12\% increases in urease activity in the landfarming plots as compared to the controls for soil $\mathrm{S}_{1}$ at the end of first to the third month of the experiment, respectively. In addition, urease activity in the landfarming plots for soil $S_{2}$ was 21,45 , 26 , and $23 \%$ higher than in the control plots at the end of first to the 4th month of the experimental period, respectively. On the other hand, urease activity decreased by passing time, particularly at the end of the last 2 months. These results correspond well to lower soil microbial respiration rate during the last days of the experimental period (Fig. 2). Environmental restrictions for microbial activity during the last 2 months of the experiment such as lower temperature and daylight hours (Fig. 1), could greatly affect the urease activity in the soil with time (Bossert and Bartha, 1985).

These results agree well with those of other authors. Marin et al. (2005) found that the urease activity at the end of the first months of their study was higher than that at the end of last months. They reported a diminishing trend for urease activity in the landfarming treatments with time. Margesin et al. (2000) concluded that all measured biological activity indicators such as urease activity can be used to monitor the diesel oil bioremediation in contaminated soil. Serrano et al. (2009) found that the increase in soil enzymatic activities (urease, dehydrogenase, BBA-protease, $\beta$-glucosidase, phosphatase, and arylsulphatase) might be resulted from the availability of a high quantity of biodegradable hydrocarbon substrates. Kucharski and Jastrzebska (2006) indicated that the increasing heating oil doses 

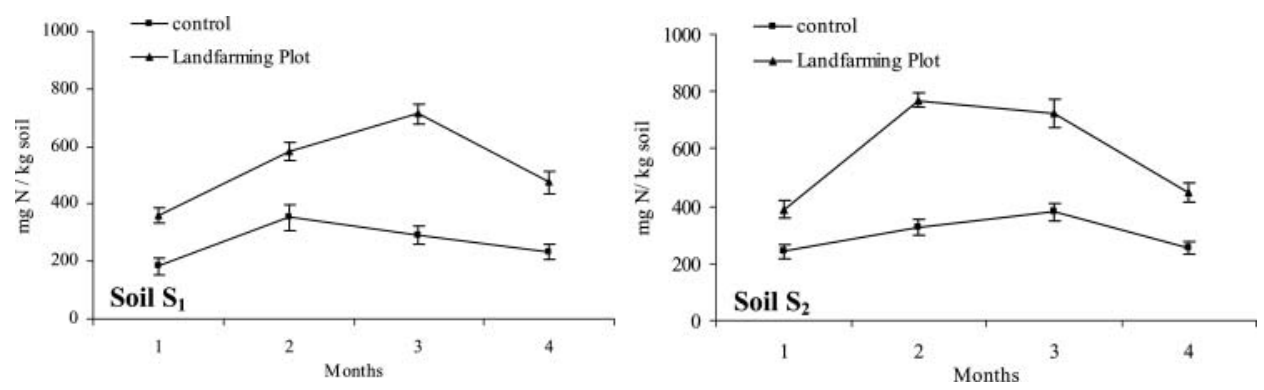

Figure 4. Microbial biomass-nitrogen in soils $S_{1}$ and $S_{2}$ during the landfarming experiment.

in lime-supplemented soil stimulated the urease activity. Visser and Parkinson (1992) reported the suitability of enzyme assays for microbial activity and soil quality assessments.

3. Microbial Biomass-Nitrogen. The microbial biomass-nitrogen (MB-N) values in the landfarming plots were considerably higher than in the control plots, indicating that the microbial biomass size and activity increased due to landfarming operations (Fig. 4). There were more than 49, 39, 52, and 51\% increases in MB-N values resulted from landfarming operations in soil $\mathrm{S}_{1}$ as compared to the controls at the end of each month of the experiment, respectively. The MB-N values in the landfarming plots in soil $S_{2}$ were also 38, 54, 48, and $43 \%$ higher than in the control plots. Furthermore, the measured MB-N values in the landfarming plots at the end of second and third months of the experiment were significantly $(P<0.05)$ higher than the other 2 months for both soils $S_{1}$ and $S_{2}$. However, no significant differences were found between the second and third months of the experiment for soil $\mathrm{S}_{2}$ (Fig. 4). The high amount of hydrocarbons and a large quantity of exogeneous organic matter in the contaminated soils at the beginning of the experiment probably inhibited the soil microbial activity and so the MB-N values (Marin et al., 2005). Seasonal variations, particularly lower temperature during the last month of the experiment (Fig. 1), may have influenced the soil microbial activity and thus the MB-N diminished in size at the end of the last month of the experiment (Nannipieri et al., 2002).

In similar studies, Joerjensen et al. (1995) found that the soil microbial biomass values increased after 165 days of incubation of nutrient-amended contaminated soil with $1 \%$ of fuel oil. Franco et al. (2004) reported a 53\% increase in microbial biomass in Mollisols contaminated with crude oil and concluded that this might be resulted from the utilization of oil hydrocarbon compounds by microorganisms as a carbon source. Marin et al. (2005) found that landfarming processes in petroleum-contaminated soil significantly enhanced the microbial biomass. Margezin et al. (1999) reported that different bioremediation treatments (with and without fertilizers) can influence the microbial biomass size and activity.

\section{Landfarming Effects on Soil Chemical Properties}

1. Soil $\mathrm{pH}$. The results of measured $\mathrm{pH}$ values in the landfarming and control plots indicated a rising trend for both soils $S_{1}$ and $S_{2}$ (Fig. 5). Soil with landfarming operations showed higher $\mathrm{pH}$ values than the controls so that significant differences $(P<0.05)$ were observed between the landfarming and control treatments at the end of most of the experimental period. It appears that successive landfarming operations may have contributed 

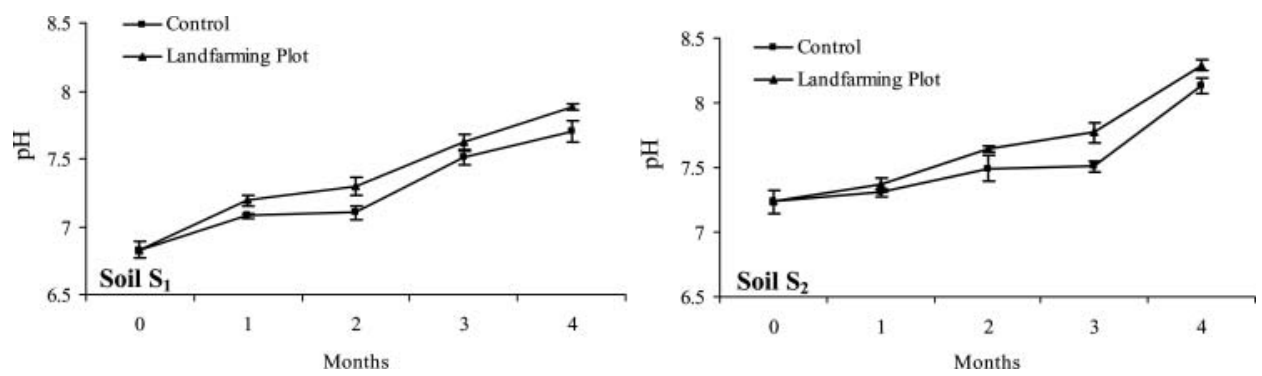

Figure 5. $\mathrm{pH}$ values in soils $\mathrm{S}_{1}$ and $\mathrm{S}_{2}$ during the landfarming experiment.

to an increasing trend for $\mathrm{pH}$ values in the landfarming plots as compared to the controls (Marin et al., 2005).

In addition, since the bioremediation of petroleum hydrocarbons using the landfarming technique is carried out by soil microorganisms, soil characteristics that influence soil microbial activity such as $\mathrm{pH}$ would also affect the degradation of these compounds. In this case, the extreme $\mathrm{pH}$ values could have a negative effect on the ability of microbial population to degrade hydrocarbons (Dibble and Bartha, 1979). In various studies, optimal $\mathrm{pH}$ values ranged from 7.5-8 have been reported for mineralization of petroleum hydrocarbons in soil (Dibble and Bartha, 1979; Atlas, 1988; Marin et al., 2005). Therefore, it seems that detected soil $\mathrm{pH}$ values in the landfarming plots in this study (Fig. 5) had probably no negative effects on microbial growth and activity.

In similar studies, Dibble and Bartha (1979) observed an optimal pH of 7.8 for mineralization of oily sludge in soil. Marin et al. (2005) reported a rising trend for $\mathrm{pH}$ values in the landfarming plots. They also mentioned a suitable $\mathrm{pH}$ value ranged from 7.5-7.65 for microbial growth in petroleum-contaminated soils. Petavy et al. (2009) reported that biodegradation, which is the main degradation process for petroleum hydrocarbon compounds in soils during the landfarming operations, is largely dependent on the conditions influencing bacterial activity, i.e. oxygen content, $\mathrm{pH}$, temperature, moisture, and nutrient contents.

2. Soil Electrical Conductivity. Soil electrical conductivity (EC) in the landfarming plots was lower than in the control plots at the end of most times of the experiment (Fig. 6). In addition, a diminishing trend with time for EC values was observed in both landfarming and
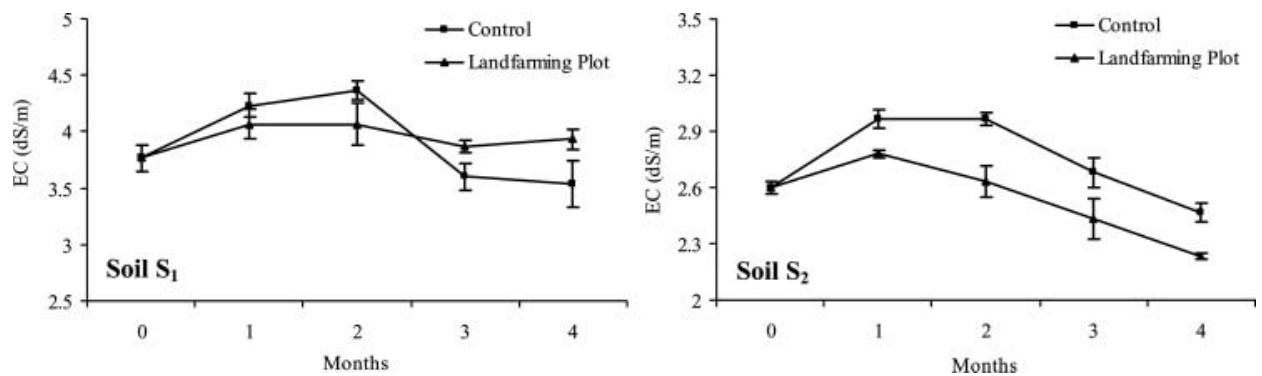

Figure 6. Electrical conductivity (EC) of soils $S_{1}$ and $S_{2}$ during the landfarming experiment. 

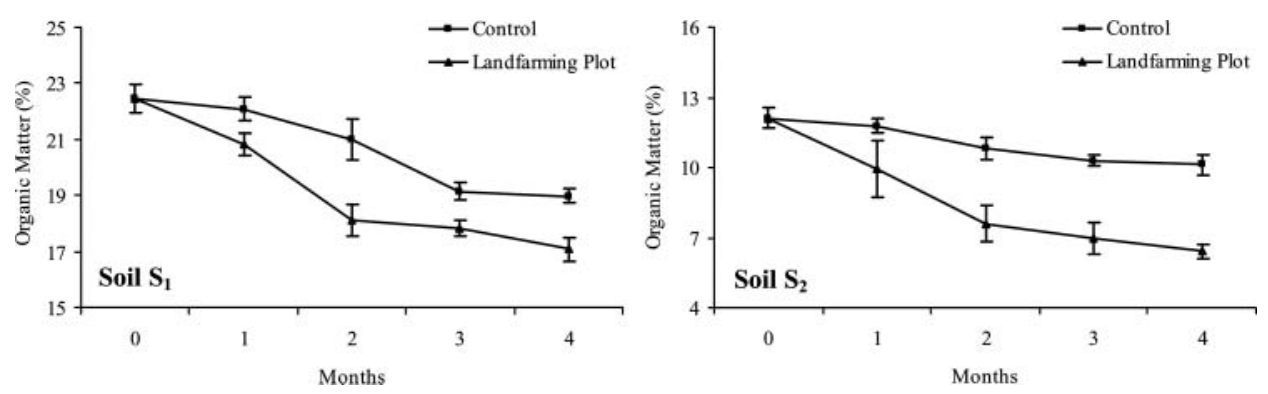

Figure 7. Organic matter content in soils $S_{1}$ and $S_{2}$ during the landfarming experiment.

control treatments; however, EC values at the end of the first 2 months of the experiment were higher than that at the beginning of the study. During the landfarming operations a large volume of water was used to maintain the soil moisture content within optimum level for microbial activities. This apparently leads to the leaching of salts and reduction of the investigated soil salinity in the landfarming plots compared to the non-irrigated control plots (Balba et al., 1998). Furthermore, degradation and mineralization of petroleum compounds in the soil during the experiment may have resulted in a diminishing trend of the EC values in the landfarming plots (Shiaris, 1989). Higher EC values in the landfarming plots as compared to the control plots for soil $S_{1}$ at the end of the last 2 months of the experiment is presumably reflected to the increasing of the concentration of salts in this treatment because of water evaporation and therefore salt concentrating near the soil surface (Balba et al., 1998). Furthermore, in the current study and according to other similar studies (Ward and Brock, 1978; Garcia and Hernandez, 1996; Marin et al., 2005), the salinity detected in the landfarming plots, especially in the soil $S_{1}$ may have negatively affected the microbial activity as well as hydrocarbon bioremediation in the soil.

3. Total Organic Matter. Total organic matter (TOM) concentration in the landfarming plots decreased by 24 and $47 \%$ for soils $S_{1}$ and $S_{2}$, respectively, at the end of experiment (Fig. 7). Furthermore, a significant difference $(P<0.05)$ was observed among the landfarming plots and controls in reduction of TOM content for both soils $S_{1}$ and $S_{2}$. The TOM decline resulted from landfarming operations in soil $S_{1}$ was $6,14,7$, and $10 \%$ higher than the controls at the end of the first to the 4th month of the experiment, respectively. Also, the TOM content in soil $\mathrm{S}_{2}$ decreased by more than $16,30,32$, and $37 \%$ in the landfarming plots as compared to the control plots (Fig. 7). Successive aeration may have contributed to the mineralization of the carbon compounds, as has been confirmed by several authors in studies of turning petroleum-contaminated and agricultural soils (Haynes and Tregurtha, 1999; Hussain et al., 1999; Marin et al., 2005; Riffaldi et al., 2006). Marin et al. (2005), for instance, observed a decrease of $27 \%$ in total organic carbon contents in the landfarming plots where the aerating and exposing new layers of petroleum-contaminated soil to sunlight and air were carried out.

4. Total Nitrogen. The effect of landfarming processes on total nitrogen (TN) contents of soil is shown in Figure 8. The results indicated that the TN concentration in the landfarming plots was lower than in the control plots during most of the experiment. However, the TN in the landfarming plots for soil $S_{1}$ was higher than in the control plots at the end of first and second months of the experiment. Furthermore, no significant differences $(P<0.05)$ were 

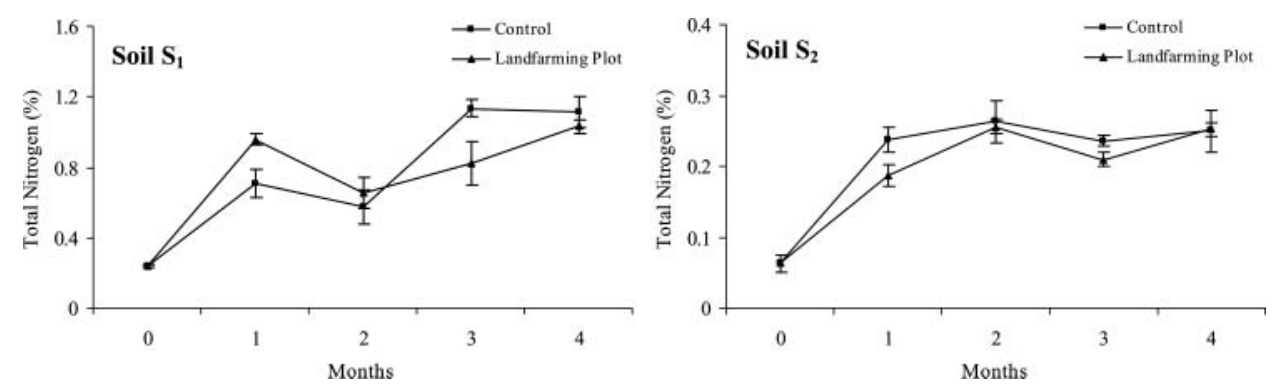

Figure 8. Total nitrogen content of soils $S_{1}$ and $S_{2}$ during the landfarming experiment.

obtained between the landfarming treatment and control at the end of last month of the experiment. A reason why the TN concentration in the landfarming plots was lower than in the control plots during most of the experiment may have been the higher consumption of N-compounds by microorganisms in the soil (Hutchinson et al., 2001).

There are limited published studies dealing with the effect of landfarming processes on total nitrogen in petroleum-contaminated soil. Hutchinson et al. (2001) reported small quantities of nitrogen compounds in the bioremediation treatments and concluded that this reduction was probably related to the consumption of nitrogen compounds by soil microorganisms.

\section{Landfarming Effects on TPH Degradation}

Landfarming operations significantly $(P<0.05)$ enhanced the degradation of hydrocarbon contaminants in both soils $S_{1}$ and $S_{2}$ in comparison to the controls (Fig. 9). There were about 50 and $57 \%$ of reductions in soil TPH concentration in the landfarming plots for soils $S_{1}$ and $S_{2}$, respectively. It appears that improved soil microbial activities as a result of aerating and exposing new layers of contaminated soil to sunlight and air by landfarming operations during the experiment (Figs. 2, 3, and 4), intensified the degradation of petroleum hydrocarbon compounds in the soil (Marin et al., 2005). Also, during the degradation process in the landfarming treatment, two clearly differentiated phases were observed: a first stage took place during the first 2 months of the experiment with a high velocity in which the hydrocarbon degradation rate was maximal (36 and 39\% of TPH concentrations were eliminated from soils $S_{1}$ and $S_{2}$, respectively) and a second, slower stage took place during
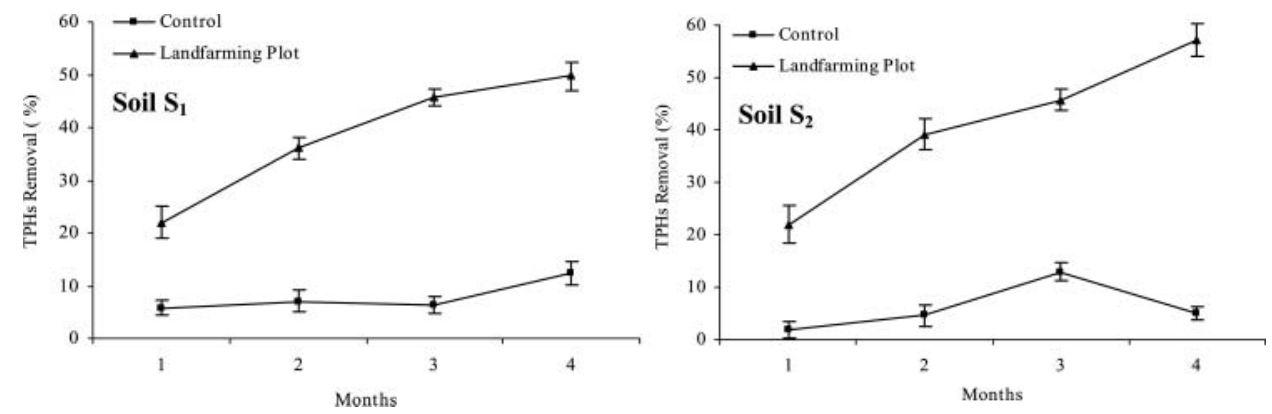

Figure 9. TPH removal from soils $S_{1}$ and $S_{2}$ during the landfarming experiment. 
the last 2 months of the experiment (lower than 13 and $17 \%$ of TPH concentrations were eliminated from soils $S_{1}$ and $S_{2}$, respectively). The first stage lasted 2 months, after which the degradation rate slowed down, demonstrating that, as the most easily biodegradable hydrocarbons were consumed, the microorganisms turned their attention to other fractions, such as the aromatic, condensed cyloalkanes, etc., that are degraded at different rates (Langbehn and Steinhart, 1995). After these 2 months, the degradation rate slowed down, the remaining fractions were structurally more complex hydrocarbons and therefore less accessible, their recalcitrance, and low bioavailability causing the activity of the microbial populations to drop (Margesin et al., 1999). Furthermore, lower temperature and daylight hours during the last 2 months of the experiment in comparison to the first 2 months (Fig. 1), might have had a further inhibitive effect on elimination of hydrocarbon compounds from soils (Atlas 1981; Langbehn and Steinhart, 1995).

In similar studies, Riffaldi et al. (2006) reported more reduction in soil TPH concentration in the bioremediation treatments as compared to the controls. Marin et al. (2005) observed more than 55\% decrease in soil TPH concentration during landfarming processes at the first 2 months of their study and lower than $45 \%$ of hydrocarbon degradation during the last 8 months. Picado et al. (2001) reported a reduction of $63 \%$ in total PAH concentration after 3 months of their landfarming experiment and concluded that the utilization of landfarming can be considered as a relatively simple and inexpensive biological treatment technique to clean up such contaminated soils. Al-Awadhi et al. (1996) concluded that the landfarming treatment resulted in more than $80 \%$ reduction of oil contamination within 15 months. Petavy et al. (2009) observed a reduction of $45-75 \%$ in total hydrocarbon concentrations at the end of their landfarming experiment. Sims and Sims (1999) reported biphasic kinetics of petroleum hydrocarbon degradation during landfarming processes. Balba et al. (1998) reported a reduction of 82 and $90 \%$ in total petroleum hydrocarbons and total alkanes contents, respectively, within a 12-month period by landfarming operation.

\section{Conclusion}

Results of the current study revealed that the landfarming operations enhanced the biodegradation of the total amount of hydrocarbons in the soils. Parameters indicative of soil microbial activity measured during the process of hydrocarbon degradation in the landfarming plots showed, in general, higher values than in the controls. However, further researches are suggested to be conducted on the study of metabolic and genetic fingerprints of the microbial community in the landfarming experiments. Improving soil aeration and exposing new layers of soil to sunlight as a result of landfarming operations also had significant effects on soil physiochemical properties.

According to the results of this study, it appears that utilization of landfarming technique may be an optimal solution to clean up persistent petroleum hydrocarbon contaminants from soil. This technique could also be used as a pretreatment in the case of contaminated soils with high TPH concentrations to overcome the limitations of high concentration of petroleum hydrocarbons and to improve the effectiveness of utilization of other remediation techniques. Nevertheless, it is necessary to add that the degradation rates of hydrocarbons may be restricted by the metabolic capabilities of the hydrocarbon-degrading microbial populations, soil physiochemical properties, and also by environmental factors. Finally, it should be considered that the studied system here was performed in conditions with no nutrient addition, which would be a great advantage in the reclamation of petroleumcontaminated soils as costs would be reduced without fertilizer amendments. 


\section{References}

Al-Awadhi, N., Al-Daher, R., ElNawawy, A., and Balba, M.T. 1996. Bioremediation of oilcontaminated soil in Kuwait. I. Landfarming to remediate oil-contaminated soil. Soil Sediment Contamin. 5 243-260.

Alef, K. 1995. Soil respiration. In: Methods in Applied Soil Microbiology and Biochemistry, Chapter 5, pp. 214-216 (Alef, K., and Nannipieri, P., eds.), Harcourt Brace \& Company Publishers, London.

Alef, K., and Nannipieri, P. 1995. Urease activity. In: Methods in Applied Soil Microbiology and Biochemistry, chapter 7, pp. 316-320 (Alef, K., and Nannipieri, P., eds.), Harcourt Brace \& Company Publishers, London.

American Petroleum Institute (API). 1983. Land Treatment Practice in the Petroleum Industry. Environmental Research and Technology Inc., Washington, DC.

Anderson, J.P.E. 1982. Soil respiration. In: Methods of Soil Analysis, Part 2, pp. 831-871 (R.W. Weaver, S. Angle, D. Bezdicek, S. Smith, and M.A. Tabatabai., eds.), American Society of Agronomy-Soil Science Society of America, Madison, Wisconsin.

Atlas, R.M. 1981. Microbial degradation of petroleum hydrocarbons: an environmental perspective. Microbiol. Rev. 45, 180-209.

Atlas, R.M. 1988. Microbiology Fundamentals and Applications, pp. 352-353, Macmillan Publishing Co., New York.

Balba, M.T., Al-Daher, R., and Al-Awadhi, N. 1998. Bioremediation of oil-contaminated desert soil: The Kuwaiti experience. Environ. Int. J. 24, 163-173.

Besalatpour, A., Khoshgoftarmanesh, A.H., Hajabbasi, M.A., and Afyuni, M. 2008. Germination and growth of selected plants in a petroleum-contaminated calcareous soil. Soil Sediment Contamin. 17, 665-676.

Bossert, I., and Bartha, R. 1985. Plant growth in soil with a history of oil sludge disposal. J. Soil Sci. 140, 418-422.

Bremner, J.M., and Mulvaney, C.S. 1982. Nitrogen-total. In: Methods of Soil Analysis, Part 2, pp. 595-624 (Page, A.L., ed.), American Society of Agronomy, Madison, Wisconsin.

Christopher, S.H., Marsden, P.J., and Sharleff, A.S. 1988. Evaluation of methods 3540 (Soxlet) and 3550 (Sonication) for evaluation of appendix IX analyses from solid samples. S-CUBED, Report for EPA contract 68-03-33-75, work assignment No. 03, Document No. SSS-R-889436.

Coulon, F., Pelletier, E., Gourhant, L., and Delille, D. 2005. Effects of nutrient and temperature on degradation of petroleum hydrocarbons in contaminated sub-Antarctic soil. Chemosphere 58, 1439-1448.

Davidson, E.A., Belk, E., and Boone, R.D. 1998. Soil and water content and temperature as independent or confounded factors controlling soil respiration in a temperate mixed hardwood forest. Global Change Biol. 4, 217-228.

Dibble, J.T., and Bartha R. 1979. Effect of environmental parameters on the biodegradation of oil sludge. Appl. Environ. Microbiol. 37, 729-739.

Franco, I., Contin, M., Bragato, G., and DeNobili, M. 2004. Microbiological resilience of soils contaminated with crude oil. Geoderma 121, 17-30.

Garcia, C., and Hernandez, T. 1996. Influence of salinity on the biological and biochemical activity of calciorthid soil. Plant Soil. 178, 255-263.

Giasi C.I., and Morelli, A. 2003. A landfarming application technique used as environmental remediation for coal oil pollution. J. Environ. Sci. Health 38, 1557-1568.

Haynes, R.J., and Tregurtha, R. 1999. Effects of increasing periods under intensive arable vegetable production on biological, chemical and physical indices of soil quality. Biol. Fert. Soils 28, 259-266.

Hejazi, R.F., Hussain, T., and Khan, F.I. 2003. Landfarming operation of oily sludge in arid region: human health risk assessment. Hazard. Mat. 99, 287-302. 
Horwath, W.R. and Paul, E.A. 1994. Microbial biomass. In: Methods of Soil Analysis, part 2, pp. 753-773 (Weaver R.W., Angel G.S., Bottomley P.S., eds.), Book Series No. 5, SSSA, Madison, Wisconsin.

Huddleston, R.L., and Meyers, J.D. 1979. Landfarming of industrial solid wastes, Research and Development Department, Continental Oil Company, In: Proceedings of the Presentation at the Annual Meeting of the Pollution Control Association of Oklahoma, Fountainhead State Lodge. 17-18 April.

Hussain, I., Olson, K.R., and Ebelhar, S.A. 1999. Long-term tillage effects on soil chemical properties and organic matter fractions. Soil Sci. Soc. Am. J. 63, 1335-1341.

Hutchinson, S.L., Banks, M.K., and Schwab, A.P. 2001. Phytoremediation of aged petroleum sludge: effect of inorganic fertilizer. Environ. Qual. 30, 395-403.

Insam, H. 2001. Developments in soil microbiology since the mid 1960s. Geoderma 100, 389-402.

Joerjensen, R.G., Schmaedeke, F., Windhorst, K., and Meyer, B. 1995. Biomass and activity of microorganisms in a fuel-oil contaminated soil. Soil Biol. Biochem. 27, 1137-1143.

Keeney, D.R., and Nelson, D.W. 1982. Nitrogen-inorganic forms. In: Methods of Soil Analysis, part 2, pp. 642-698 (Page A.L., Miller R.H., Keeney D.R., eds.), SSSA, Madison, Wisconsin.

Kucharski, J., and Jastrzebska, E. 2006. Effect of heating oil on the activity of soil enzymes and the yield of yellow lupine. Plant Soil Environ. 52, 220-226.

Langbehn, A., and Steinhart, H. 1995. Biodegradation studies of hydrocarbons in soil by analyzing metabolites formed. Chemosphere 30, 855-867.

Leiros, M.C., Trasar-Cepeda, C., Seoane S., and Gil-Sotres, F. 1999. Dependence of mineralization of soil organic matter on temperature and moisture. Soil Biol. Biochem. 31, 327-335.

Margesin, A., Walder, G., and Schinner, F. 2000. The impact of hydrocarbon remediation (diesel oil and polycyclic aromatic hydrocarbons) on enzyme activities and microbial properties of soil. Acta Biotechnol. 20, 313-333.

Margesin, A., Zimmerbauer, A., and Schinner, F. 1999. Monitoring of bioremediation by soil biological activities. Chemosphere 40, 339-346.

Marin, J.A., Hernandez, T., and Garcia, C. 2005. Bioremediation of oil refinery sludge by landfarming in semiarid conditions: Influence on soil microbial activity. Environ. Research 98, 185-195.

Merkle, N., Karft, R.S., and Infant, C. 2005. Assessment of tropical grasses and legumes for phytoremediation of petroleum-contaminated soils. Water Air Soil Pollut. 165, 195-209.

Nannipieri, P., Kandeler, E., and Ruggiero, P. 2002. Enzyme activities and microbiological and biochemical processes in soil. In: Enzymes in the Environment Activity, Ecology and Applications, pp. 1-35 (Burns, R.G., Dick, R.P., eds.), Marcel Dekker, New York.

Nelson, D.W., and Sommers L.E. 1982. Total carbon, organic carbon, and organic matter. In: Methods of Soil Analysis, Part 2, pp. 539-579 (Page, A.L., ed.), American Society of Agronomy, Madison, Wisconsin.

Petavy, F., Ruban, V., Conil, P., Viau J.Y., and Auriol, J.C. 2009. Two treatment methods for stormwater sediments—pilot plant and landfarming — and reuse of the treated sediments in civil engineering. Environ. Technol. 30, 825-830.

Picado, A., Nogueira, A., Baeta-Hall, L., Mendonca, E., De Fatima Rodrigues, M., Do Ceu Saagua, M., Martins, A., and Anselmo, A.M. 2001. Landfarming in a PAH-contaminated soil. J. Environ. Sci. Health 36, 1579-1588.

Pope, D.F., and Matthews, J.E. 1993. Bioremediation Using the Land Treatment Concept. US.EPA/600/R-93/164. Robert S. Kerr, Environmental Research Laboratory, US Environmental Protection Agency, Ada, OK.

Riffaldi, R., Levi-Minzi, R., Cardelli, R., Palumbo, S., and Saviozzi, A. 2006. Soil biological activity in monitoring the bioremediation of diesel oil-contaminated soil. Water Air Soil Pollut. 170, $3-15$.

SAS Institute. 1999. SAS/STAT User's Guide, release 8.2. SAS Institute, Cary, NC.

Serrano, A., Tejada, M., Gallego, M., and Gonzalez, J.L. 2009. Evaluation of soil biological activity after a diesel fuel spill. Sci. Total Environ. 407, 4056-4061. 
Shiaris, M.P. 1989. Seasonal biotransformation of naphthalene, phenanthrene, and benzo[a]pyrene in surficial estuarine sediments. Appl. Environ. Microbiol. 55, 1391-1399.

Siddiqui, S., and Adams, W.A. 2002. The fate of diesel hydrocarbons in soils and their effect on the germination of Perennial Ryegrass. J. Environ. Pollut. 118, 49-62.

Sims, R.C., and Sims, J.L. 1999. Landfarming of petroleum contaminated soils. In: Bioremediation of Contaminated Soils, pp. 767-781 (Adriano, D.C., Bollag, J.M., Sims, R.C., eds.), Agronomy. No. 37. SSSA, Madison, Wisconsin.

Visser, S., and Parkinson, D. 1992. Soil biological criteria as indicators of soil quality: Soil microorganisms. Am. J. Altern. Agric. 7, 33-37.

Ward, D.M., and Brock, T.D. 1978. Hydrocarbons biodegradation in hyper saline environments. Appl. Environ. Microbiol. 35, 353-359.

Xu, S.Y., Chen, Y.X., Wu, W.X., Wang, K.X., Lin, Q., and Liang, X.Q. 2006. Enhanced dissipation of phenanthrene and pyrene in spiked soils by combined plants cultivation. Sci. Total Environ. 363, 206-215. 